\title{
Pengaruh Penerapan Strategi Scaffolding Terhadap Ketuntasan Hasil Belajar Peserta Didik SMA Negeri 4 Banda Aceh Pada Submateri Tata Nama Senyawa Hidrokarbon
}

\author{
Faizah Muna Nabila ${ }^{1)}$, Abdul Gani ${ }^{2)}$, Habibati ${ }^{3)}$ \\ Prodi Pendidikan Kimia FKIP Universitas Syiah Kuala, Darussalam Banda Aceh 2311 \\ e-mail: faizahmunanabila@gmail.com
}

\begin{abstract}
It has conducted the research entitled, “The Effect of Implementation of Scaffolding Strategy in Students' Learning Outcomes in Nomenclature of Hydrocarbons Subject at SMAN 4 Banda Aceh". This research was conducted by using quantitative approach and the type of this research was experimental research. The subject of this research was class XI IPA 2 as control class and XI IPA 3 as experimental class, which consist of 30 students and 31 students. The technique of data collection of this research was the test and observation. Meanwhile, the research instrument of this study was test (pre-test, daily test, and observation sheet attitudes of the students). The data analyzed by using t-test and formula to prove the hypothesis. Based on the hypothesis, $\mathrm{H}_{\mathrm{o}}$ is accepted since $\mathrm{t}$-value is $1,853<2,0409$. The result showed that the percentage of the experimental class students' learning outcomes is 73,15 greater than control class that is $69,66 \%$ with an average value is 2,82 and 2,78 . The ratting attitudes of the students processed by using the formula, which the result is 74,8 in the eksperimental class and $73,16 \%$ in the control class. Based on the result, it can be concluded that there is no significant improvement in the students' learning outcomes in the nomenclature of hydrocarbon subject.
\end{abstract}

Key Words : Scaffolding, Students' Learning Outcomes, Nomenclature of Hydrocarbons.

Abstrak. Telah dilakukan penelitian dengan judul pengaruh penerapan strategi scaffolding terhadap ketuntasan hasil belajar peserta didik SMA Negeri 4 Banda Aceh pada submateri tata nama senyawa hidrokarbon. Penelitian ini dilakukan dengan menggunakan pendekatan kuantitatif dengan jenis penelitan eksperimen. Subjek penelitian yaitu kelas XI IPA 2 sebagai kelas kontrol dan XI IPA 3 sebagai kelas eksperimen dengan jumlah peserta didik sebanyak 30 dan 31 orang. Teknik pengumpulan data yaitu tes dan observasi. Instrumen penelitian yang digunakan yaitu berupa soal tes (tes awal dan ulangan harian) serta lembar observasi sikap. Data yang diperoleh diolah dengan menggunakan uji-t untuk membuktikan hipotesis serta rumus persentase. Berdasarkan uji hipotesis hasil yang diperoleh yaitu $\mathrm{H}_{\mathrm{o}}$ diterima karena hasil $\mathrm{t}_{\text {hitung }}<\mathrm{t}_{\text {tabel }}$ yaitu $1,853<2,0409$. Hasil penelitian menunjukan hasil belajar peserta didik kelas eksperimen sedikit lebih tinggi dari kelas kontrol dengan persentase sebesar $73>69,66 \%$. Penilaian sikap secara klasikal diolah dengan menggunakan rumus persentase dengan hasil rata-rata sebesar $74,8 \%$ pada kelas eksperimen dan $73,16 \%$ pada kelas kontrol. Berdasarkan hasil penelitian ini maka dapat disimpulkan bahwa tidak terdapat pengaruh penerapan strategi scaffolding terhadap ketuntasan hasil belajar peserta didik pada submateri tata nama senyawa hidrokarbon.

Kata kunci : Scaffolding, Ketuntasan Hasil Belajar, Tata Nama Senyawa Hidrokarbon.

\section{PENDAHULUAN}

Pendidikan merupakan aspek penting dalam kehidupan yaitu untuk meningkatkan dan mengembangkan potensi manusia agar menjadi SDM yang berkualitas. Usaha dalam meningkatkan kualitas SDM terus dilakukan pada berbagai jenjang pendidikan agar mencapai tujuan pendidikan nasional. Kegiatan proses belajar mengajar disekolah merupakan usaha yang nyata dalam meningkatkan kualitas pendidikan nasional dikarenakan sekolah merupakan salah satu perangkat pendidikan. Salah satu mata pelajaran yang wajib dipelajari pada jenjang Sekolah Mengengah Atas (SMA) adalah kimia.
Ilmu kimia terdiri dari konsep yang bersifat abstrak dan kompleks sehingga diperlukan pemahaman konsep agar dapat menguasainya. Salah satu materi yang diajarkan yaitu materi hidrokarbon. Menurut Agustina, Nugroho dan Mulyani (2013), materi hidrokarbon membutuhkan pemahaman konsep yang kuat dan bersifat komperhensif. Pada materi hidrokarbon peserta didik dituntut untuk dapat mengenal senyawa hidrokarbon, mengetahui tata nama senyawa hidrokarbon, isomer serta sifat dan kegunaan senyawa hidrokarbon dalam kehidupan sehari-hari.

Berdasarkan hasil observasi dan wawancara yang telah dilakukan terhadap dua orang guru kimia kelas XI SMA Negeri 4 Banda Aceh pada tanggal 23 
Maret 2016 diperoleh data hasil ketuntasan belajar dari nilai rata-rata ulangan harian pada tahun ajaran 2015/2016 pada materi hidrokarbon yaitu 57sehingga masih dikategorikan tidak tuntas karena dibawah nilai ketuntasan minimal yang telah ditetapkan sekolah tersebut yaitu 66,75. Salah satu upaya yang dapat dilakukan yaitu dengan menerapkan strategi scaffolding.

Scaffolding dideksripsikan sebagai bantuan yang diberikan kepada peserta didik oleh orang yang memiliki pengetahuan lebih seperti guru atau teman sebaya dalam menyelesaikan tugas yang tidak mampu dilaksanakannya, (Wood, Bruner \& Ross, 1976). Lebih lanjut Janneke, (2010),"Scaffolding adalah bantuan yang diberikan oleh guru ketika peserta didik tidak mampu mengerjakan tugas yang diberikan tanpa adanya bantuan". Bantuan yang diberikan oleh pendidik (guru) dapat berupa petunjuk, peringatan, dorongan, menguraikan masalah ke dalam bentuk lain yang memungkinkan peserta didik dapat mandiri, (Mamin, 2008). Pemberian bantuan harus disesuaikan dengan zona proximal development (ZPD) peserta didik. Scaffolding merupakan praktik berdasarkan konsep Vgyotsky mengenai ZPD yang dapat diartikan sebagai Daerah Perkembangan Terdekat (Vonna, Mukminatien, dan Laksmi, 2015).

Menurut Vygotsky, perkembangan kemampuan seseorang dapat dibedakan ke dalam dua tingkat, yaitu tingkat perkembangan aktual dan tingkat perkembangan potensial. Tingkat perkembangan aktual tampak dari kemampuan seseorang untuk menyelesaikan tugas-tugas atau memecahkan berbagai masalah secara mandiri. Sedangkan tingkat perkembangan potensial tampak dari kemampuan seseorang untuk menyelesaikan tugas-tugas dan memecahkan masalah ketika di bawah bimbingan orang dewasa atau ketika berkolaborasi dengan teman sebaya yang lebih kompeten (Yohanes, 2010).

Dalam pembelajaran formal, scaffolding diharapkan mampu mendukung peserta didik dalam mencapai tujuan pembelajaran yang diharapkan sehingga mampu menyelesaikan tugas yang diberikan Hmelo-Silver, dll., 2007) . Berdasarkan uraian di atas, maka peneliti tertarik untuk melakukan penelitian dengan judul "Pengaruh Penerapan Strategi Scaffolding Terhadap Ketuntasan Hasil Belajar Peserta Didik SMA Negeri 4 Banda Aceh pada Submateri Tata Nama Senyawa Hidrokarbon”.

\section{METODE PENELITIAN}

Pendekatan yang digunakan pada penelitian ini ialah pendekatan kuantitatif. Jenis penelitian yang digunakan adalah quasi eksperimen berupa nonequivalent control group design dengan bentuk desain penelitian berupa pre-test dan post-test (Sugiyono, 2010). Metode penelitian eksperimen ditandai dengan membandingkan dua kelompok yaitu kelompok kontrol dan kelompok eksperimen yang menerima perlakuan. Sampel pada penelitian ini diambil secara purposive sample yaitu kelas XI IPA 2 sebagai kelas kontrol dan kelas XI IPA 3 sebagai kelas eksperimen atas pertimbangan waktu, (Arikunto, 2010).

Data yang dikumpulkan pada penelitian ini yaitu penilaian sikap yang diperoleh salama proses pembelajaran dengan diobservasi oleh empat orang observer. Hasil belajar berupa pre-test dan ulangan harian yang kemudian diakumulasi menjadi nilai post-test. Teknik pengolahan data dilakukan dengan menggunakan uji-t dengan syarat data berdistribusi normal dan homogen sesuai dengan yang dikemukan oleh Sudjana (2005). Adapun rumus uju-t yaitu:

$$
t_{\text {hitung }}=\frac{\mathrm{X}_{1}-\mathrm{X}_{2}}{s \sqrt{\frac{1}{n_{1}}+\frac{1}{n_{2}}}}
$$

\section{HASIL DAN PEMBAHASAN}

Penelitian mengenai penerapan strategi scaffolding pada submateri tata nama senyawa hidrokarbon dilakukan untuk melihat apakah ada pengaruh penerapan strategi tersebut terhadap ketuntasan hasil belajar peserta didik. Adapun jenis penelitian yang digunakan yaitu eksperimental. Jenis penelitian ini ditandai dengan adanya kelas kontrol sebagai pembanding terhadap kelas eksperimen yang diberikan perlakuan sesuai dengan aspek yang ingin diteliti dengan memberikan perlakuan berupa pemberian pre-test di awal pembelajaran dan posttest diakhir pembelajaran.

Proses pembelajaran pada kelas kontrol dilakukan dengan menerapkan pendekatan scientifik sesuai dengan kurikulum yang berlaku pada sekolah tersebut. Pada tahap pembelajaran, peserta didik terlebih dahulu mengerjakan pre-test . Adapun hasil analisis data, rata-rata nilai pre-test kelas kontrol yaitu 28,3. Proses pembelajaran kemudian dimulai dengan memberikan penjelasan kepada peserta didik mengenai materi tata nama senyawa alkana.

Pada tahap selanjutnya peserta didik dibagikan kedalam lima kelompok secara heterogen. Pembagian kelompok ini dilakukan berdasarkan kelompok belajar sebelumnya yang telah ditentukan oleh guru mata pelajaran. Proses pembelajaran dilakukan dengan menggunakan model pembelajaran STAD 
dimana peserta didik belajar secara kolaboratif sesuai dengan pendekatan pembelajaran yang diterapkan. Hal ini sesuai dengan Salasiah (2012), "STAD (Student Teams Achievement Devision) merupakan salah satu sistem pembelajaran kooperatif yang di dalamnya siswa dibentuk dalam kelompok belajar yang terdiri dari empat atau lima anggota, kelompok diupayakan heterogen".

Selama proses belajar, peserta didik terlibat aktif berdiskusi dalam menyelesaikan tugas. Hal tersebut dapat dilihat dari banyaknya peserta didik yang aktif dalam bertanya mengenai bagian yang tidak dipahami yaitu terutama pada langkah-langkah penomoran serta penentuan struktur senyawa alkana. Namun, proses penyelesaian tugas berupa LKPD yang diberikan tidak dapat diselesaikan tepat waktu. Hal ini dikarenakan peserta didik terlambat masuk kelas setelah jam istriahat siang berakhir sehingga proses pembelajaran menjadi kurang efektif.

Berbeda dengan pertemuan pertama, proses pembelajaran mengalami progres yang signifikan. Hal ini dikarenakan pada materi yang diajarkan yaitu penamaan senyawa alkena dan alkuna memiliki langkah-langkah yang sama dengan senyawa alkana sehingga peserta didik mudah dalam menyelesaikan tugas. Hanya saja kendala yang ditemui yaitu pada langkah penomoran dikarenakan penomoran dimulai dari yang paling dekat dengan ikatan rangkap. Setelah semua kegiatan inti selesai, pada tahap akhir pembelajaran kepada peserta didik kemudian diberikan soal tes untuk mengevaluasi hasil belajar selama 25 menit dan berakhir dengan tepat waktu.

Pertemuan pertama dikelas eksperimen yaitu kelas XI IPA 3 diberikan perlakuan yang sama dengan kelas kontrol yaitu berupa pre-test sebelum dimulainya proses pembelajaran. Pemberian pre-tes tdilakukan untuk melihat perbandingan hasil belajar peserta didik sebelum dan setelah perlakuan serta untuk mengecek prior learning peserta didik. Hal ini sesuai dengan Mamin (2008) menyatakan, "mengecek hasil belajar sebelumnya (prior learning) dalam hal ini kita menentukan zona of proximal development masing-masing peserta didik. Peserta didik kemudian dikelompokkan menurut level perkembangan awal yang dimiliki atau pada ZPD yang relatif sama. Peserta didik dengan ZPD yang jauh berbeda dengan kemajuan rata-rata kelas dapat diberi perhatian khusus".

Berdasarkan hasil pre-test, nilai rata-rata yang diperoleh kelas eksperimen sebesar 30,64 yang kemudian peserta didik dikelompokkan kedalam 5 kelompok sesuai dengan zona perkembangannya. kelompok 1 berada pada tingkatan less dependence stage dikarenakan nilai rata-rata yang dimiliki yaitu 2 dengan rentang antara 2-2,65. Adapun kelompok 2, 3 , 4, dan 5 berada pada tingkatan more dependence other stage karena berada pada rentang nilai 1-1,65. Hal ini sesuai dengan Tharp \& Galimore (1988) menyatakan bahwa ZPD terdiri dari empat tingkat yaitu: tingkatan sangat mebutuhkan bantuan, tingkat kurangnya kebutuhan terhadap bantuan, tingkat internalisasi terhadap bantuan, dan tingkatan optimalisasi.

Proses pembelajaran dilanjutkan dengan pembagian LKPD pada masing-masing kelompok. LKPD diberikan sebagai bentuk tugas yang disediakan oleh guru. Hal ini sesuai dengan Majid (2015) menyatakan bahwa scaffolding adalah strategi pembelajaran dimana peserta didik belajar dalam pembelajaran yang telah dipersiapkan sesuai dengan pengetahuan awal yang dimiliki. Lebih lanjut Nusu (2014) menyatakan, "scaffolding dapat berupa pemberian tugas yang disiapkan oleh guru. Agar scaffolding berjalan dengan efektif, tugas-tugas tersebut harus berada pada ZPD".

Setelah dibagikannya LKPD pada masingmasing kelompok, proses pembelajaran kemudian dilanjutkan dengan memberi penjelasan mengenai materi pembelajaran. Penjelasan merupakan tahap awal dalam penerapan pembelajaran sebelum diberikannya scaffolding sesuai dengan kebutuhan peserta didik hingga mampu memahami konsep yang diajarkan. Menurut Bikmaz, dkk (2010), “penjelasan adalah suatu pernyataan dalam mengambarkan sesuatu agar peserta didik memahami tentang apa yang sedang dipelajari, serta mengapa, kapan dan bagaimana ia digunakan".

Beberapa kesulitan yang dialami oleh peserta didik dalam pemberian nama senyawa alkana yaitu pada langkah penentuan rantai induk pada senyawa alkana yang memiliki cabang lebih dari satu, penomoran serta penentuan rumus struktur senyawa alkana berdasarkan nama senyawanya. Bantuan yang paling banyak diberikan yaitu pada kelompok 4 dan 5 pada penentuan rantai induk. Oleh karena itu scaffolding (bantuan) yang diberikan yaitu berupa modeling. Pemberian contoh dilakukan kepada masing-masing kelompok tersebut dengan memberikan contoh soal yang mirip dengan soal yang serupa pada LKPD.

Setelah diberikannya contoh, masih terdapat beberapa peserta didik di kelompok 4 dan 5 yang masih salah dalam menentukan penomoran. Peserta didik pada kelompok 4 yang mengalami kesulitan yaitu AS, RM, dan KA serta CR dan ZA pada kelompok 5 yaitu dalam menentukan rantai penomoran pada senyawa alkana sehingga bantuan yang diberikan hanya berupa petunjuk dengan 
mengingatkan kembali cara penentuan rantai induk seperti contoh yang sudah diberikan yang kemudian mereka mencoba menyelesaikan soal pada LKPD. Seiring berkembangnya keterampilan dan pengetahuan peserta didik dengan adanya dukungan, maka pemberian scaffolding di kurangi hingga akhirnya mampu mengerjakan dengan mandiri tugas yang diberikan (Chang, Chen dan Sung, 2002).

Kendala lain yang ditemui oleh semua kelompok yaitu penentuan rumus struktur senyawa alkana. Bantuan yang diberikan berupa modeling atau pemberian contoh penyelesaian masalah tersebut. Dalam hal ini, peneliti harus memberikan contoh serta penjelasan ulang dikarenakan peserta didik masih sulit dalam memahaminya. Hal ini sesuai dengan Pressley dalam Khasanah (2012) mendefinisikan pemodelan sebagai cara guru dalam menunjukkan bagaimana seseorang harus merasa, berpikir atau bertindak dalam situasi tertentu pada proses pembelajaran. Hal ini dimaksutkan bahwasanya guru memberikan pemodelan/ contoh cara menyelesaikan suatu permasalahan dalam pembelajaran.

Berbeda dengan kelompok 4 dan 5, kemajuan yang signifikan dialami oleh kelompok 1 dan 2 dimana bantuan yang dibutuhkan hanya berupa petunjuk dan peringatan karena mereka cenderung masih salah dalam menuliskan nama senyawa alkana dengan menggunakan huruf kapital dan berspasi. Pemberian bantuan tersebut sesuai dengan apa yang dibutuhkan oleh peserta didik yang mana merupakan karakteristik pertama dari scaffolding berupa contingency atau perbedaan. Hal ini sesuai dengan Lin, dkk (2012) menyatakan, "berkembangnya ZPD peserta didik maka pemberian scaffolding harus disesuaikan seiring dengan berkembangnya pengetahuan dan keterampilannya".

Pada pertemuan kedua, proses pembelajaran masih dilakukan didalam kelompok dengan mengerjakan LKPD yang diberikan. Materi yang diajarkan merupakan tata nama senyawa alkena dan alkuna. Dikarenakan peserta didik secara keseluruhan sudah memahami langkah-langkah penaman senyawa alkana, maka tidak sulit bagi mereka untuk memahami penamaan senyawa alkena dan alkuna. Sama halnya dengan kelas kontrol kendala utama yang ditemui oleh peserta didik yaitu rumus struktur senyawa alkena dan alkuna, dikarenakan berdasarkan aturan penomoran, ikatan rangkap harus didahulukan dari pada penomoran nama pada cabang. Oleh karena itu, peneliti memberikan beberapa contoh lain kepada seluruh kelompok mengenai cara penyelesaiannya.
Secara keseluruhan, proses pembelajaran pada pertemuan kedua lebih baik dan lebih efefktif yaitu dikarenakan langkah-langkah penamaan senyawa alkena dan alkuna hampir sama hanya saja pada tahap penomorannya saja yang berbeda. Disisi lain dikarenakan peserta didik sudah menghafal namanama senyawa alkana, alkena dan alkuna serta namanama alkil sehingga lebih memudahkan dalam proses pengerjaan tugas dalam LKPD lebih cepat selesai.

Tahap akhir dari proses pembelajaran yaitu melakukan ulangan harian pada tiap akhir pertemuan dengan soal berupa pilihan ganda dengan total 10 soal. Nilai ulangan harian kemudian diakumulasikan menjadi nilai post-test. Berdasarkan hasil analisis data, persentase ketuntasan hasil belajar peserta didik kelas eksperimen dan kelas kontrol yaitu sebesar 73 dan $69,66 \%$. Namun, ketuntasan hasil belajar peserta didik pada kelas kontrol dan kelas eksperimen tidak memiliki perbedaan yang signifikan hanya berbeda $3,4 \%$. Adapun nilai rata-rata ketuntasan hasil belajar dapat dilihat pada Gambar 1.

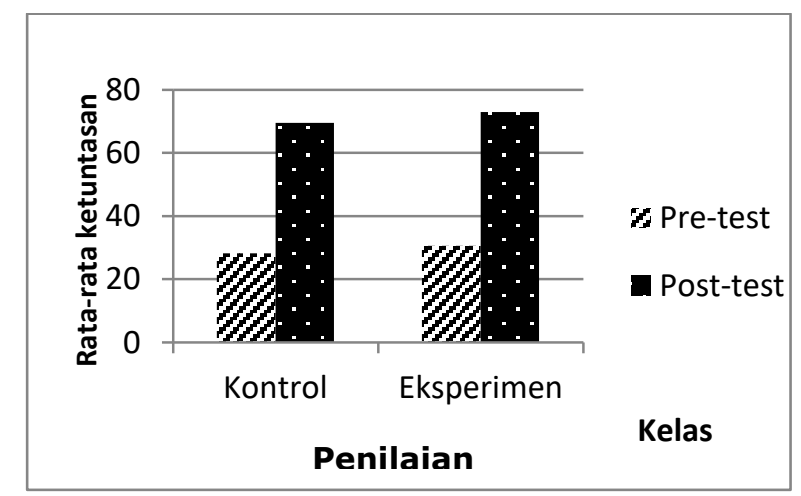

Gambar 1. Grafik Nilai Ketuntasan Hasil Belajar

Berdasarkan tabel diatas, nilai rata-rata ketuntasan hasil belajar kelas eksperimen yaitu sebesar 73 dan kelas kontrol sebesar 69,6. Hal ini menunjukkan pada kedua kelas tersebut secara keseluruhan dapat dikategorikan tuntas dikarenakan berada diatas nilai KM yang telah ditentukan oleh sekolah yaitu 66,75. Hal ini sejalan dengan hasil penelitian Akani (2015), "peserta didik yang mendapatkan perlakukan berupa penerapan scaffolding yaitu kelas eksperimen memiliki skor rata-rata 26,67 dengan standar deviasi (SD) sebesar 5,13 sedangkan kelas kontrol yang menggunakan pengajaran secara konvensional memiliki skor ratarata yaitu 18,21 dengan SD 3.94. Hasil yang diperoleh memperlihatkan hasil perbedaan yaitu sebesar 8,46. Oleh karena itu, strategi scaffolding mampu membuat peserta didik lebih memahami pelajaran serta mencapai tujuan pembelajaran".

Berkembangannya kemampuan peserta didik dapat dibuktikan dengan meningkatanya hasil belajar 
yang diperoleh yang artinya zona potensial peserta didik sudah berkembangan dengan baik. Hal ini dapat dilihat dari ketuntasan yang dimiliki. Dari 31 orang peserta didik, hanya 8 orang diantaranya masih dikategorikan tidak tuntas karena memiliki nilai dibawah KM yang telah ditentukan. Adapun 8 orang peserta didik tersebut yaitu AS, AK, CR, KA, MF, MR, RM dan RN dengan nilai akhir sebesar 65, 60, 50, 55, 65, 60 60, 60 dan 55. Namun, kemampuan peserta didik tersebut telah menggalami peningkatan dikarenakan mereka telah mencapai tingakatan selanjutnya dari ZPD.

Penilaian lain yang dilakukan yaitu pada penelitian ini yaitu penilaian observasi sikap peserta didik. Data mengenai hasil observasi sikap dapat dilihat pada Gambar 2.

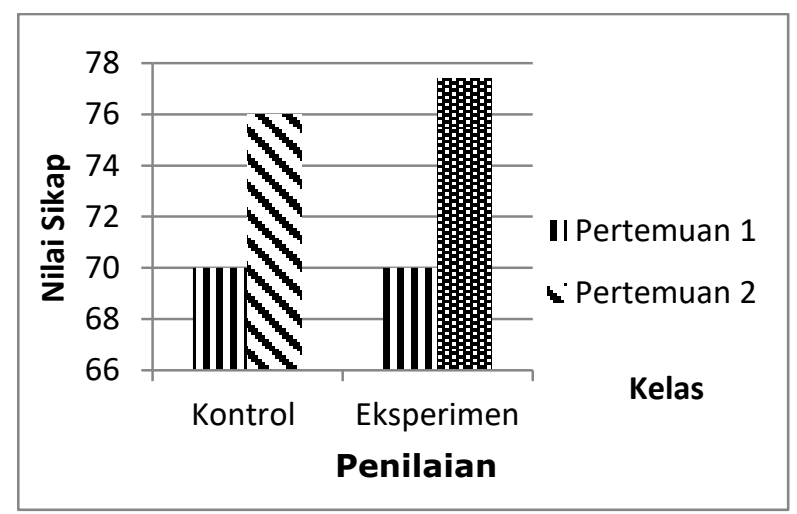

Gambar 2. Nilai Observasi Sikap

Berdasarkan Gambar 2, secara keseluruhan nilai sikap peserta didik pada kelas kontrol dan kelas eksperimen dapat dikatakan baik. Penilaian terhadap sikap peserta didik pada penelitian ini meliputi lima aspek yaitu disiplin, santun, komunikatif, kerja sama serta tanggung jawab. Kelima aspek tersebut dinilai sesuai dengan kompetensi dasar pada materi hidrokarbon. Kelima aspek tersebut diukur dengan menggunakan lembar observasi sikap dan dilakukan pada kelas kontrol dan kelas eksperimen oleh empat orang observer.

Berdasarkan hasil observasi, sikap disiplin,tanggung jawab serta komunikatif peserta didik masih harus ditingkatkan lagi. Stone (1998) menekankan bahwa pentingnya komunikasi yang baik antara guru dan peserta didik dapat mengembangkan kemapuannya dalam memahami pemebelajaran. Salah satu hal yang dapat menyukseskan hasil belajar sesuai dengan strategi scaffolding yang diterapkan yaitu adalah sifat komunikatif.

Berdasarkan hasil pengolahan data yang telah dilakukan dengan menggunakan uji-t maka tidak terdapat pengaruh penerapan strategi scaffolding terhadap ketuntasan hasil belajar peserta didik pada submateri tata nama senyawa hidrokarbon. Hal tersebut sesuai perhitungan dengan menggunakan uji$\mathrm{t}$, dimana nilai $\mathrm{t}_{\text {hitung }}<\mathrm{t}_{\text {tabel }}$ yaitu $1,853<2,0409$ sehingga hipotesis alternatif $\left(\mathrm{H}_{\mathrm{a}}\right)$ ditolak dan hipotesis nol $\left(\mathrm{H}_{\mathrm{o}}\right)$ pada penelitian ini diterima.

Ada beberapa penyebab proses pembelajaran pada kelas eksperimen tidak berjalan dengan efektif, yaitu kurangnya sikap komunikatif peserta didik sehingga interaksi menjadi tidak optimal. Pada proses pembelajaran berlangsung, peserta didik cenderung tidak bertanya ketika tidak memahami materi yang diberikan sehingga peneliti sulit mengetahui kesulitan yang dimiliki oleh peserta didik sehingga sulit dalam meberikan bantuan dan berakibat pada penyelesaian tugas yang diberikan.

Vygostky dalam Kearsely (2012) menyatakan bawa, "interkasi sosial merupakan pondasi utama dalam membangun pemahaman peserta didik disertai dengan penerapan scaffolding dalam proses pembelajaran".Lebih lanjut Vygostky (1978) mengatakan bahwa, "bahasa merupakan alat manusia dalam komunikasi dan komunikasi merupakan alat budaya. Peserta didik mengkreasi pengetahuannya dan mengembangkan pemahaman dengan belajar untuk menyampaikan dan mempertahankan pemikirannya serta membahas dengan sesamanya" Hal ini menyebabkan peneliti harus memahami kesulitan peserta didik secara personal maupun kelompok dengan mengobservasi langsung satu persatu kelompok pada bagian mana mereka kurang memahaminya sehingga pemberian bantuan menjadi kurang optimal.

Disisi lain, perbedaan kemampuan yang terlalu besar pada kelompok 1 dengan kelompok lainnya menyebabkan proses belajar berlangsung lambat dimana peserta didik yang sudah mampu memahami dan mengerjakan tugas yang diberikan cenderung bosan dalam belajar. Hal ini sesuai dengan Khasanah (2012) yang menyatakan bahwa, "peserta didik yang memiliki kemampuan yang baik cenderung lebih cepat dalam menyelesaikan tugas yang diberikan ketika peserta didik yang lain masih mengerjakannya. Hal ini menyebabkan peserta didik tersebut merasa frustasi karena bosan menunggu guru untuk melanjutkan proses pembelajaran. Salah satu solusi yang dapat dilakukan yaitu mengharapkan peserta didik membantu peserta didik lainnya sebagai dalam proses scaffolding ini”.

Hal lain yang jadi penyebab kurang optimalnya pembelajaran menggunakan strategi scaffolding yaitu karena pembagian kelompok seharusnya dilakukan secara heterogen berdasarkan nilai ulangan harian dengan tingkat kemampuan peserta didik yang 
berbeda-beda sehingga pada penyelesaian tugas yang diberikan peserta didik yang memilki kemampuan lebih dapat memberikan bantuan kepada peserta didik yang lain dalam menyelesaikan tugas yang diberikan oleh guru. Pemberian tugas yang diberikan juga harus disesuaikan dengan ZPD peserta didik. Pemberian tugas diberikan secara bertahap dan bertingkat sehingga pemberian bantuan juga dapat disesuaikan dengan kebutuhan peserta didik.

\section{PENUTUP}

\section{A. Simpulan}

Berdasarkan hasil penelitian mengenai penerapan strategi scaffolding terhadap ketuntasan hasil belajar peserta didik pada subamteri tata nama senyawa hidrokarbon diperoleh kesimpulan sebagai berikut:

1. Tidak terdapat pengaruh penerapan strategi scaffolding terhadap ketuntasan hasil belajar pada subamteri tata nama senyawa hidrokarbon.

2. Persentase ketuntasan hasil belajar belajar kelas eksperimen $73 \%$ dan kelas kontrol sebesar $69,66 \%$ dengan perbedaan sebesar $3,4 \%$.

\section{B. Saran}

Hasil penelitian ini akan maksimal jika diterapkan pada sekolah yang lain agar hasilnya bisa diterapkan secara menyeluruh. Penelitian ini sampai batas mengetahui pengaruh pada satu sekolah. Agar bisa digenralisasi penulis menyarankan bahwa hasil penelitian ini diterapkan kembali pada sekolah yang kainnya.

\section{DAFTAR PUSTAKA}

Agustina, E, Nugroho, A dan Mulyani, S. 2013. Penggunaan Metode Jigsaw Berbantuan Handout Untuk Meningkatkan Aktivitas dan Prestasi Belajar Siswa pada Materi Pokok Hidrokarbon Kelas XC SMA Negeri 1 Gubug Tahun Ajaran 2012/2013. Jurnal Pendidikan Kimia. 2(4): 66-71.

Akani, O. 2015. Impact of Instructional Scaffolding on Student's Acchievement in Chemistry in Secondary School in Ebonyi State of Nigeria. International Journal of Education, Learning and Development. 3(7): 74-83.

Arikunto, S. 2010. Prosedur Penelitian Suatu Pendekatan Praktis. Jakarta: Rineka Cipta.

Bikmaz, F.H., dkk. 2010. Scaffolding Strategies Applied by Student Teachers to Teach Mathematics. The International Journal of Research in Teacher Education. (1): 25-36.

Chang, K., Chen, I., \& Sung, Y. 2002. The Effect of Concept Mapping to Enhance Text Comprehension and summarization. The
Journal of Experimental Education 71(1): 523.

Hmelo-Silver CE, Duncan RG, Chinn CA. 2007. Scaffolding and achievement in problem based and inquiry learning: a response to Kirschner, Sweller, and Clark (2006). Journal of Education Psychology. 42(2):99-107.

Janneke, VDP, Volman, M dan Beishuizen, J. 2010 Scaffolding in Teacher-Student Interaction: A Decade of Research. Education Psychology Review. (22): 271-296.

Kearsley, G. S. 1989. Instructional variables and mathematics achievement in face-to-face and distance teaching modes. International Council of Distance Education Bulletin. (4): 15-31.

Khasanah, U.F. 2012. Improving Student's Speaking Skill Using Scaffolding Startegy: A Classroom Action Research at the Seventh Grade of SMP Negeri 4 Sukuharjo in The Academic Year of 2010/2011. Tesis. Surakarta: Universitas Sebelas Maret.

Lin, T.C., dkk. 2012. A Review of Emperical Evidence on Scaffolding for Science Education. International Journal of Science and Mathematic Education. (10): 437-455.

Majid, A.H.B., Stapa, S.H., Keong, Y.C. 2015. Blended Scaffolding Strategies Through Facebook for Learning and Improving The Writing Process and Writing Performance. Journal of Social Science and Humanities. (1): 31-39.

Mamin, R. 2008. Penerapan Strategi Pembelajaran Scaffolding pada Pokok Bahasan Sistem Periodik Unsur. Jurnal Chemica. 10 (2): 5560.

Nazir, M. 2009. Metode Penelitian. Bandung: Ghalia Indonesia.

Nusu, A. 2014. Scaffolding dalam Mikroteaching Kimia Berbasis Pembelajaran Langsung dan Siklus Belajar. Jurnal Ilmu Pendidikan. 20 (1): 37-46.

Salasiah. 2012. Meningkatkan Partisipasi dan Hasil Belajar Siswa Kelas X-A dalam Penguasaan Konsep Penggolongan Hidrokarbon di SMA Negeri 1 Tanta Melalui Model Pembelajaran Kolaboratif STAD-Make A Match. Jurnal Inovasi Pendidikan Sains. 3(2): 147-152.

Stone, A. 1998. The Metaphor of Scaffolding: Its Utility for the Field of Learning Disabilities. Journal of Learning Disabilities. 3 (4): 344364.

Sudjana. 2005. Metoda Statistika. Bandung: Tarsito. 
Sudijono, A. 2009. Pengantar Statistik Pendidikan. Jakarta: Rajawali Press.

Sugiyono. 2010. Metode Penelitian Pendidikan Pendekatan Kuantitatif, Kualitatif dan R\&D. Jakarta: Alfabeta.

Tharp, R.G. dan Gallimore, R., 1988, Rousing minds to life: Teaching, learning, and Schooling in Social Context. New York: Cambridge University Press.

Vonna, Y., Mukmanatien, N., dan Laksmi, E.D. 2015. The Effect of Scaffolding Techniques on Students' Writing Achievement. Jurnal Pendidikan Humaniora. 3 (1): 227-233.

Vygotsky, L. S. 1978. Mind in Society: The Development of Higher Psychological Processes (M.Cole, V. John-Steiner, S. Scribner, \& E. Souberman, Eds.) Cambridge, MA: Harvard University Press.

Wood, D., Bruner, J. S. dan Ross, G. 1976. The role of tutoring in problem solving. Journal of Child Psychology and Psychiatry, and Allied Disciplines. 17 (2): 89-100.

Yohanes, R.S. 2010. Teori Vygotsky dan Implikasinya Terhadap Pembelajaran Matematika. Widya Warta. (2): 127-135. 